Jasone Cenoz, Durk Gorter and Stephen May

Language Awareness and Multilingualism

Encyclopedia of Language and Education

3rd ed.

10.1007/978-3-319-02325-0_1-2

Accepted Manucript; S. 3-17

\title{
Language Awareness and Multilingualism: A Historical Overview
}

Claudia Finkbeiner ${ }^{1}$ and Joanna White ${ }^{2}$

(1)Faculty of Humanities, Department of English, University of Kassel, Kurt-Wolters-Straße 5, 34125 Kassel, Germany

(2)Department of Education, Concordia University, 1455 de Maisonneuve Blvd. W., H3G $1 \mathrm{M} 8$ Montreal, QC, Canada

\section{Claudia Finkbeiner (Corresponding author) \\ Email: cfink@uni-kassel.de}

Joanna White (Corresponding author)

Email: joanna.white@concordia.ca

\section{Abstract}

In this encyclopedia entry, language awareness and multilingualism will be reviewed from a historical perspective, and current research trends will be highlighted. There is not a direct relationship between both movements from the beginning; rather there have been parallel (independent) developments. With the world becoming increasingly interconnected, multilingualism and diversity have turned into an everyday experience in various domains of life. While the field of language awareness initially concentrated on English L1 teaching, its scope and principles nowadays are much broader, including a wide variety of languages and contexts, such as L2 and L3 learning; bi-, tri-, and multilingual education; content- and language-integrated learning; and computer-/mobile-assisted learning. An examination of the articles published in the Language Awareness journal and the International Journal of Multilingualism between 2010 and the beginning of 2015 revealed that both language awareness and multilingualism encompass a wide range of topics and languages. On the whole, however, the primary focus still seems to be on English and language education, with communication in other languages and in the workplace remaining relatively unexplored. Although there are a number of well-designed small-scale studies, larger comparative studies that include and compare different settings and languages are needed. Altogether, it appears that the fields of language awareness and multilingualism can be fruitfully combined, with language awareness playing an important role in the development of multilingualism. In that regard, critical awareness of the role of politics is crucial since political decisions influence language use and the official status of languages as well as a person's (multilingual) identity.

Keywords Attitudes - Borders - CLIL programme - Cognitive abilities - Computer-based langue 
learning - Cultural awareness - Emotions - Foreign language studies - Forensic linguistics - Garrett, P. - Hawkins, E. - Intercomprehension - Interconnected world - James, C - Knowledge about language Language education - Language awareness - Language instruction - Language policy Multilingualism - Nature of language - Pedagogical activities - Pre-school language acquisition School curriculum - Teacher language awareness - Teacher training

\section{Introduction}

There is no doubt that language awareness and multilingualism have become important issues in our increasingly interconnected world. When the wall separating East and West Berlin fell in 1989, many people hoped that a new era had begun in which disagreements between East and West would be resolved peacefully. However, conflicts and wars have continued around the globe since then, many of which have arisen from misunderstanding other perspectives. Indeed, sometimes wars of weapons are supplemented by wars of rhetoric as even the language and drawings in cartoons can lead to disastrous conflicts. For example, the satire printed in Charlie Hebdo caused a cultural conflict which ended in a massacre in Paris in 2015. An immediate response was the appearance of the slogan "je suis Charlie," coined as a sign of solidarity with the victims and support for freedom of the press. Along with geographical borders between nation states, we find mental, cultural, and linguistic borders existing in people's heads and separating them just as weapons do. However, instead of developing into new weapons, languages and cultures have the potential to become vehicles that bring people together and allow new connections to be made. We begin this chapter by defining language awareness and tracing its history over the past 50 years, from a pedagogical initiative in the UK to an international association with its own journal. Next, we provide a survey of the current topics in the Language Awareness journal, The International Journal of Multilingualism, and in other research. Following this overview, we look at language awareness issues in education and the role that language awareness can play in our interconnected world.

\section{Early Developments}

\section{Language Awareness: Definitions and History}

"Language awareness" (LA) has been defined as "a person's sensitivity to and conscious awareness of the nature of language and its role in human life" (Donmall $\underline{1985}$, in Donmall-Hicks $\underline{1997}$, p. 21). The term initially referred to pedagogical initiatives that had been undertaken in England in response to the report of the Bullock Committee in 1975 and that were primarily related to mother tongue learning. The Bullock report, which investigated the teaching of English as a mother tongue and/or language of instruction, emphasized the importance of knowledge about language (KAL) ${ }^{1}$ for the entire school curriculum and recognized the potential benefits that could result from cooperation between mother tongue (English) and modern language teachers who, historically, had operated independently. The National Congress for Languages in Education (NCLE), established to facilitate this cooperation, set up the Language Awareness Working Party in 1982 to gather theoretical support and to survey teachers to identify schools where language awareness initiatives were already in place. They found seven such schools throughout England, Wales, Scotland, and Northern Ireland, prepared 
an annotated bibliography, organized a conference in Leeds, and published a report edited by Donmall $(\underline{1985})$.

By the mid-1980s, language awareness had become a movement in the UK. At the beginning of the 1990s, James and Garrett ( $\underline{1991}$ ) identified five domains of language awareness. In the cognitive domain, LA focused on language patterns. Its main goals were to promote LA in the teaching and learning of all subjects across the school curriculum and to recognize its potential as a subject in its own right that could bridge the space between mother tongue and foreign language instruction.

Hawkins $(\underline{1987 a}, \underline{b})$ hoped that for children aged 11-14, language awareness would facilitate the start of foreign language studies by connecting different aspects of language education (English, modern languages, and minority languages). To achieve this goal, he suggested contrasting the new (foreign) language with languages the students already knew (see also James 1996).

In the affective domain, language awareness focused on attitudes and emotions . LA was seen as a means to promote tolerance and understanding towards the different varieties of English and the many home languages spoken by students in the schools. ${ }^{2}$ In the social domain, LA focused on the role of language in effective communication and interaction. In the power domain, LA was intended to alert people to the potential for language to be used as an instrument of manipulation. And in the performance domain, the hope was that increased awareness would have a positive effect on learners' "command of the language" (see James and Garrett 1991, pp. 17-20). ${ }^{3}$ Looking back, Donmall-Hicks noted that "... LA was viewed as an enabling field, designed to facilitate people's access to one another through language, to make available the language to talk about language, ${ }^{4}$ and to reduce jargon. Its starting point was the removal of barriers, which was to remain its essence" ( $\underline{1997}$, p. 22). However, bilingual and multilingual perspectives were still largely missing.

\section{The Institutionalization of Language Awareness and Multilingualism}

The early 1990s were important for the formal recognition of language awareness in the UK and beyond. In 1992, the British Council, the Goethe-Institut, and the French Embassy held a symposium that led to the launching of a new journal, Language Awareness, with an international editorial board of 21 members from 13 different countries. In the first issue that appeared in the same year, each of the five articles discussed aspects of LA in education in a different European context: England and Wales (Hawkins); the Netherlands (van Essen); France (Candelier); Spain (Prieto Pablos); and Ireland (Singleton). However, the board made a "special plea for subsequent issues for relevant work which concerns the rest of life, e.g., pre-school language acquisition, also the world of work and issues in language sensitive professions such as the law and politics. National and international perceptions of language, for example the changing moods in Europe, will be of considerable interest for most readers" (Language Awareness $\underline{1992}$, p. 3). With a journal already in place and 84 founding members, the Association for Language Awareness (ALA) was formally established in 1994 at a conference held in Plymouth, UK.

\section{The Association for Language Awareness Defines Language Awareness}

as explicit knowledge about language , and conscious perception and sensitivity in language learning, language teaching and language use. It covers a wide spectrum of fields. For example, language 
awareness issues include exploring the benefits that can be derived from developing a good knowledge about language, a conscious understanding of how languages work, of how people learn them and use them. (ALA 2012, retrieved September 7th 2016)

In France, a pedagogical initiative known as éveil aux langues (awakening to languages) emerged in the 1990s, led by Michel Candelier, one of the founders of the Association for Language Awareness. Éveil aux langues (EVLANG) provides opportunities, through a variety of pedagogical activities, for school children to engage with audio and written corpuses in many different languages and to develop "both positive attitudes towards the cultural and linguistic diversity of the world in which they live, and the desire to learn various languages" (EDiLiC 2009, retrieved July 8th 2015). The EVLANG approach, supported by the European Union, was implemented in other European countries and beyond (e.g., ELODIL in Canada). In 2001 the international EDiLiC association was set up by partners of the EVLANG program to disseminate awakening to languages internationally. The European Commission ( 2007, in Cenoz 2013, p. 5) defines multilingualism as "the ability of societies, institutions, groups and individuals to engage, on a regular basis, with more than one language in their day-to-day lives." In this definition, multilingualism includes bilingualism. Although the main focus of the journal Language Awareness was initially on awareness in first and second language contexts, its mandate was broad enough to include the ability to use three or more languages. Indeed, the first article on the use of more than two languages in the journal appeared in 1993 and discussed LA issues in and out of school in multilingual Belgium (Goethals 1993).

\section{Major Contributions}

\section{Issues and Research in Language Awareness and Multilingualism from 2010 to 2015}

In this section, we provide an overview of articles that appeared in the Language Awareness journal and The International Journal of Multilingualism for the period 2010 to the beginning of 2015. In Language Awareness there is a wide spectrum of articles that discuss the role of LA in learning and teaching. To identify the topics more narrowly, we first surveyed the titles and keywords. The following themes emerged: the construct of language awareness, genre teaching, bilingual and trilingual teaching, curriculum, teacher training, teacher language awareness , grammar, vocabulary, literary awareness, graphonemic treatment, word formation, phonemic awareness, metalinguistic awareness, language attitudes and motivation, peer feedback, awareness of L1-L2 differences, language diaries and code choice, intercultural awareness, language ideology, self regulated and cooperative learning, and computer-based language learning.

Many of the journal topics are directly related to the biannual conferences of the ALA. Whereas the organizers of the first conferences did not see the need to formulate a specific title for the meeting as the focus was clearly set on broad issues related to language awareness, organizers in recent years have set specific conference themes: "Engaging with Language" in Hong Kong in 2008, "Language, Culture and Literacy" in Kassel in 2010, "Language Awareness for our Multicultural World" in Montreal in 2012, "Language Awareness - Achievements and Challenges" in Hamar, Norway in 2014, and "Languages for Life: Educational, Professional and Social Contexts" in Vienna in 2016. The conference in Vienna is a response to the call for research on the role of language awareness and 
cultural awareness in the workplace with multilingual communities (Cenoz and Genesee 1998, p. VII) in super diverse cities.

Next we looked at the languages investigated in Language Awareness from 2010 to 2015. Even though the LA movement started with a strong focus on English as an L1, current research includes a variety of other languages as well: Irish, Welsh, Spanish, Basque, Catalan, Portuguese, German, Hebrew, French, Greek, Italian, Dutch, Japanese, Mandarin, Chinese, Danish, and Indonesian. It is striking, however, that some topics have been discussed solely with respect to English: teacher language awareness , teacher training, and computer-based language learning. There is clearly a need for publications that report research involving other languages in these fields.

The first issue of the International Journal of Multilingualism was published in 2004. A look at the articles that appeared in this journal from 2010 to 2015 revealed the following themes: phonology, dual and multilanguage systems, bilingualism, trilingualism and multilingualism, linguistic nationalism, language transfer, foreign language learning, identity, the multilingual reader, and metrolingualism (a new term that looks at language as a construct situated in time and space). Other themes play an important role, such as migrant languages, ethnolect/ethnographic studies, selfformation, multilingual literacies, linguistics and ideological conflict, gender, study abroad, prior knowledge, socio-affective factors (e.g., motivation), multiple language acquisition, nexus analysis of language processes, code-switching/language-switching, social inclusion, language policy, transnationalism, Lingua Franca, the role of the teacher in a multilingual classroom, brain processes, and discursive and transglossic practices and change. Even though there is a range of target languages, English is still given the most attention, followed by other widely spoken languages such as French, German, and Spanish.

\section{Work in Progress}

\section{Language Awareness and Multilingualism in Schools}

The European Union has declared multilingualism an important goal for all member states. The policy aims at protecting language diversity on the one hand and teaching languages on the other. The European Framework of Reference regulates and demands multilingual language competence in Europe. Each European citizen should understand at least two languages other than the mother tongue. When the approach relates to language families, such as the Romance or Germanic languages, it is called intercomprehension (Capucho et al. 2011). Even though multilingualism and intercomprehension have not been fully implemented, a lot of energy and funds have been spent on language learning and mobility in Europe. Intercomprehension so far seems to be more of a grassroots movement with publications on how to implement the approach. Big scale empirical studies on the effects of intercomprehension, such as incidental vocabulary learning, have yet to be conducted. There is a growing number of projects in Europe with a special focus on developing the language and cultural awareness of elementary school children (see, for example, Helot and Young 2002, 2006, in France and the JALIN project in Switzerland by Perregaux 2005). Krumm's (2001) project with the language silhouette, which aimed at creating awareness among children with respect to their individual multilingual diversity, has been implemented by Martin ( 2012) and others in several contexts and settings. Beyond Europe, a number of language and cultural awareness projects have been carried out in elementary schools in Canada (e.g., Dagenais et al. 2009). 


\section{Teacher Language Awareness}

As we have said above, the language awareness movement was initially concerned with first and second language learning and teaching. From this perspective, teacher language awareness is an important prerequisite for teaching language awareness. The question is whether or not teachers who are not language aware themselves can teach or foster students' language awareness (Andrews 2007). Despite this important issue, there still seems to be a research gap, and publications explicitly focusing on teacher language awareness (TLA) are rare in the Language Awareness journal as well as in the International Journal of Multilingualism. In a number of publications that focus on grammar and the metalinguistic awareness of teachers, Andrews (e.g., 1997, 2003) provides an introduction to the nature of TLA, assesses its impact upon teaching, and its potential impact on learning. Although there are a number of well-designed small studies on TLA, larger studies that include and compare different settings and languages are needed. One such study was conducted by Lasagabaster and Huguet (2007), who, together with an international team of scholars, compared language use and language attitudes in multilingual contexts in Europe. The focus was on contexts where a regional language, such as Basque, Catalan, Frisian, and Welsh, played a role. The starting point was the demand of the European Union that European citizens become proficient in at least three European languages: their primary mother tongue and two other European languages. The same research design was used in all of the bilingual contexts, and the data were analyzed using the same techniques. One of the most important findings was that teachers' awareness of linguistic diversity plays an important role in the development of multilingualism.

Another important large-scale study is the one by Bangma et al. (2011). Knowledge about early multilingualism among learners at the beginning of their school career is at the center of interest of this research. The study aimed at describing trilingual primary immersion education in eleven multilingual regions in Europe: Finland, the Basque Country, Fryslân, Catalonia, Aosta Valley, Aran Valley, the Balearic Islands, Carinthia, Luxembourg, North Frisia, and the Valencial Community. The authors defined trilingualism such that all three target languages were to be taught as school subjects as well as used as the medium of instruction. The study, an update of the one by Beetsma ( 2002), showed that there is great variation in trilingual teaching. In comparison to the earlier study, more attention was given to (meta-)linguistic awareness. Among the challenges that were observed, a major one was the oftentimes low language proficiency of the language teachers in the three languages (Riemersma 2011) and their lack of pedagogical knowledge and skills.

LA has developed into a relevant topic in non-language subjects, as well. This can be seen in the growing number of schools around the world that offer content and language-integrated (CLIL) programs or bilingual programs. In CLIL classrooms, subjects such as history, geography, political sciences, natural sciences, and physical education are taught in the target language. Ideally, awareness is raised of conceptual similarities and differences through comparisons of mother tongue(s), first, second, and third foreign languages (Finkbeiner and Fehling 2006).

Fehling (2008) conducted a comparative longitudinal study in three grammar schools in Hesse, Germany, with students in CLIL contexts. She investigated the development of language awareness in monolingual subject matter classes (such as history) versus bilingual (English-German) CLIL classrooms over 2 years. Her focus was on three domains of language awareness: cognitive, social, and political (James and Garrett 1991). The outcomes showed that bilingual students had better cognitive abilities right from the outset that developed further during the 2 years of the study, which shows the selective character of the CLIL program. Furthermore, after 2 years students in the bilingual classes had developed more interest in the subject and more self-confidence regarding their 
English-speaking skills. The cognitive abilities of the monolingual students in comparison showed no significant development.

Another factor that comes into play when we are looking at TLA is cross-cultural attitudes. In this regard, an international transatlantic 2-year-long study (TRANSABCS; Finkbeiner and Lazar 2015) was implemented at 12 colleges and universities across the USA and Europe. It aimed at developing language awareness and cultural awareness among teacher candidates and business majors through the use of autobiographies, biographies, and cross-cultural analyses (ABCs) (Schmidt and Finkbeiner 2006). An important finding is that the ABCs made the most significant impact on the group that was the least open to cultural heterogeneity at the beginning of the intervention (Finkbeiner 2015).

\section{Language Awareness and Multilingualism in the Workplace}

To date, studies on language awareness and multilingualism in the workplace are still needed, as are those investigating language awareness in relationships such as between doctor-patient, customerclient, or employer-employee. This research is important, particularly in diversified workplaces where differing underlying concepts and opposing interpretations might lead to misunderstanding and failure in work processes. In air navigation and medicine, for example, misunderstandings could contribute to the escalation of events and even be life-threatening. Also, attitudes toward dialects and language choices, as well as attitudes toward code-switching, can play a decisive role in whether or not a job applicant is successful. In the context of the migration hat has hit Europe since 2015 language awareness as well as awareness for the legal issues of language use as dealt with in forensic linguistics play an important role for the integration of refugees in the workplace. Language awareness and multilingualism in the workplace are crucial factors in super diverse communities and cannot be ignored. Research in this area would fill a gap in the literature.

\section{Issues and Difficulties}

\section{The Role of Language Awareness in Our Interconnected World}

Critical literacy (Fairclough 1992) has become an important democratic value in a world that has developed into an interconnected network shared by many. This requires awareness that democratic structures only exist on the surface layer as social networks are dictated by the few who own them. New technologies have an effect on students' daily behavior, as well as their language learning, and critical language awareness becomes more and more important with respect to media use. This is why a special issue of the Language Awareness journal was dedicated to this topic in 2007 (Palfreyman 2007). Today not only computers can be used to create meaningful learning environments (computerassisted language learning, CALL), but also mobiles (mobile-assisted language learning, MALL) and wearable technologies such as smart watches and smart wristbands. This is a new opportunity as there is easy access: more and more young people carry mobiles and/or wearable technologies. In a language-aware CALL or MALL learning environment, students need to learn about the pluses and minuses of social networks. They should also become aware of language change in and through the media with respect to the oral and written mode as well as emoticons and discourse style. They need to relearn the distinction between public vs. private, official vs. nonofficial discourse, learn to deal with cyberbullying and apply proper netiquette. Furthermore, gender issues play a role in online 
communication. As Deutsch ( 2007, p. 116) has pointed out, "gender is 'always lurking' in interactions." If this is true, conventions that differ for male, female and other interaction, for example will be observed in online communication (style, length, politeness, use of emoticons, etc.). The use of media thus requires new competencies. It is not only the critical use of language that students have to learn but also the critical use of the media.

\section{Language Regulation and Educational as well as Individual Needs}

Although there are around 5,000-7,000 languages worldwide ${ }^{5}$, a few languages predominate in the interconnected world described above. According to the Ethnologue, $40 \%$ of the world's population are speakers of the eight most common languages, namely Mandarin, Hindi, Spanish, English, Bengali, Portuguese, Arabic, and Russian (Gordon 2005 in Cenoz 2009, p. 1). Around 6.1\% of all people speak minority languages, such as Frisian, Basque, Welsh, Irish, and Catalan in Europe. In diversifying multilingual communities (Cenoz and Genesee 1998), language choices often are political decisions. There are different ways in which languages are protected and/or promoted. A language protective situation is given in Switzerland: here the languages Swiss, German, French, and Italian are protected by declaring an official national multilingual status. This is the same with Canada, where English and French function as two official languages. The province of New Brunswick is officially bilingual, and in the province of Quebec, French is the official language. Language policy has always been seen as the vehicle of nation building, and political changes usually bring language changes. For example, in postwar Germany the languages of the allies were taught: English and French in the West Zone and Russian in the East Zone. After the fall of the Berlin Wall, language policy changed from the top down, and this has enabled the learning of "Western" languages. As a consequence, most learners in the former East Zone have opted for English. In Hungary, Dörnyei ( 2001) investigated the foreign language motivation and preference of 4,765 primary school children after the fall of the Iron Curtain. Half of all children learned Russian, the other half learned German or English. Independently of regions and languages taught, the majority of all children preferred English once they had freedom of choice.

Pliska ( 2015) carried out an empirical study in eleven schools in Bosnia-Herzegovina with 515 eighth-grade elementary school pupils. Whereas the pupils were positive about learning foreign languages, English in particular, their attitudes towards the official languages of Bosnia-Herzegovina (Bosnian, Croatian, and Serbian) were dependent on whether they accepted the respective language variation as a mother tongue and could identify themselves with it. Their own individual variation (Serbian, Bosnian, or Croatian) allowed strong group identification and was valued as positive, whereas the other two variations were perceived as negative. Furthermore, most pupils defined Serbian, Bosnian, and Croatian as three different languages.

Examples like these show the impact of language policies on language teaching and learning. Language instruction is subject to change - not because of learners' needs but mainly for political and/or economic or dialect reasons.

\section{The Role of the Association for Language Awareness Today: Voices from Around the World}

The issues that prompted the founding of the Association for Language Awareness (ALA) were UK based, and many of the original members were in the UK. While ALA was mainly concerned with 
defining itself in the 1990s, ALA now sees itself as a way of bringing scholars and practitioners together. This will likely be the way ahead in the future as the profile of the members becomes more varied and less Europe centered, and their concerns relate to a wider variety of contexts. While English is still the predominant language being investigated, members from countries in Asia, Africa, the Middle East, North and South America, and Europe present their research on a variety of languages at the biannual ALA conferences. In a recent unpublished survey, ALA members identified the following topics as important to investigate: multilingual language users; intercultural communication; issues related to minority languages; and integration of the curricula of different languages. As well, there is a growing interest in the potential impact of language awareness on the workplace and in the role that critical language awareness can play in challenging stereotypes and negative language attitudes of the general public, politicians, and educators.

\section{Conclusions and Future Directions}

We can conclude that because of the increase in multilingualism in schools and in the workplace, LA has a major role to play. However, the growth of multilingualism is paralleled by the dominance of "monolingualism" in academic publications (e.g., Carli and Ammon 2007). According to Guardiano et al. (2007), only 20\% of all articles published in English in a global context are written by nonnative speakers. According to the philosopher's index, the share of English in selected journals of the social sciences and humanities was $82.5 \%$ in 1995, followed by French with 5.9\%, German with $4.1 \%$, Spanish with $2.2 \%$, and other languages with 5.3\%. The same is true for English as the most important abstract language. Another database study was conducted in the Philosopher's Index 20 years later in 2015 with the two main constructs of this chapter as search terms: language awareness and multilingualism. The hypothesis was that a search with constructs that focus on the role of language awareness and multilingualism would increase the likelihood of finding multilingual contributions. The Philosopher's Index yielded 14,419 hits for the construct language awareness in total, out of which 13,372 hits (93\%) were in English, 387 (2.7\%) in German, 168 (1.2\%) in French, $75(0.5 \%)$ in Portuguese, $67(0.46 \%)$ in Italian, and $61(0.42 \%)$ in Spanish/Castilian. For the construct "multilingualism" the index yielded 4,822 hits in total, out of which 4,173 (85\%) were in English, 247 (5\%) in German, 247 (5\%) in French, $57(1.2 \%)$ in Italian, 42 (0.9\%) in Spanish, and $28(0.6 \%)$ in Esperanto. This underlines the fact that the predominance of English as the publication language in the humanities has increased even more over the last 20 years.

According to Hamel ( 2007), the predominance of English in the natural sciences at the end of the twentieth century is even more striking. The fact that the current debate about multilingualism and language awareness is primarily conducted from an English monolingual perspective can be seen as counterproductive. This leads to an imbalance with respect to scholars' voices around the world. As the phenomenon of "the Anglophone's free ride" (van Parijs 2007) is still acute today, we can conclude that research results and discussions have to be published in English to be noticed. This also applies to scholars publishing in the field of language awareness and multilingualism. According to van Parijs, this is not just a language issue, but a market value and economic advantage issue as well. One suggestion is that academic multilingualism should be fostered in language-sensitive disciplines: "The larger aim would be to create a multilingual comfort zone, where scholars could communicate in the language of their choice, e.g., at conferences and in publications" (Schluer 2014, p. 10). This links back to the concept of intercomprehension.

The language awareness and multilingualism movements first developed separately and consecutively. In the meanwhile, they have become important reciprocally relevant interdisciplinary 
research constructs: language awareness studies cannot ignore multilingualism as a factor nor can multilingualism studies ignore language awareness. Therefore, both movements have become crucial assets for the further development of the field.

\section{Cross-References}

Attention and Awareness

Knowledge About Bilingualism and Multilingualism

\section{Related Articles in the Encyclopedia of Language and Education}

Bernard Spolsky: Language Policy in Education: History, Theory, Praxis. In Volume: Language Policy and Political Issues.

Elinor Ochs; Bambi Schieffelin: Language Socialization: An Historical Overview. In Volume: Language Socialization

\section{Acknowledgments}

We wish to acknowledge Christine Busque, Montreal, Canada as well as to Ina Sauer and Anna Petzold, Kassel Germany for their support in data base research. We also thank Richard Aplin for information on the very start of the language awareness movement and to Jennifer Schluer, Kassel, Germany for her help in final proof reading and editing.

\section{References}

ALA. (2012). About language awareness. Association for language awareness. http://www. languageawareness.org/web.ala/web/about/tout.php. Accessed 6 Feb 2015.

Andrews, S. (1997). Metalinguistic awareness and teacher explanation. Language Awareness, 6(2-3), 147-161. doi:10.1080/09658416.1997.9959924.

CrossRef

Andrews, S. (2003). Teacher language awareness and the professional knowledge base of the L2 teacher. Language Awareness, 12(2), 81-95. doi:10.1080/09658410308667068.

CrossRef

Andrews, S. (2007). Teacher language awareness (Cambridge language teaching library).

Cambridge: Cambridge University Press.

CrossRef 
Bangma, I., van der Meer, C., \& Riemersma, A. (2011). Trilingual primary education in Europe; Some developments with regard to the provisions of trilingual primary education in minority language communities of the European Union. Liouwert/Leeuwarden: Fryske Akademy.

Beetsma, D. (Ed.). (2002). Trilingual Primary Education in Europe. Inventory of the provisions for trilingual primary education in minority language communities of the European Union. Leeuwarden: Fryske Akademy.

Capucho, F., Degache, C., Martins, A., Meißner, F.-J., Spiţă, D., \& Tost, M. A. (Eds.). (2011). Intercomprehension: Learning, teaching, research - apprentissage, enseignement, rechercheLernen, Lehren, Forschung. Akten des Europäischen Netzwerks Interkomprehension (REDINTER) im Rahmen des 3. Bundeskongresses des Gesamtverbandes Moderne Fremdsprachen, Universität Augsburg, 16-18 Sept 2010. Tübingen: Narr Francke Attempto.

Carli, A., \& Ammon, U. (Eds.). (2007). Linguistic inequality in scientific communication today (AILA review, Vol. 20). Amsterdam/Philadelphia: John Benjamins.

Cenoz, J. (2009). Towards multilingual education. Basque educational research from an international perspective. Bristol/Buffalo/Toronto: Multilingual Matters.

Cenoz, J. (2013). Defining multilingualism. Annual Review of Applied Linguistics, 13, 3-17. CrossRef

Cenoz, J., \& Genesee, F. (1998). Introduction. In J. Cenoz \& F. Genesee (Eds.), Beyond bilingualism: Multilingualism and multilingual education (p. VII). Clevedon: Multilingual Matters.

Dagenais, D., Moore, D., Sabatier, C., Lamarre, S., \& Armand, F. (2009). Linguistic landscape and language awareness. In E. Shohamy \& D. Gorter (Eds.), Linguistic landscape: Expanding the scenery (pp. 253-269). New York: Routledge/Taylor \& Francis Group.

Deutsch, F. M. (2007). Undoing gender. Gender and Society, 21(2), 106-127.

CrossRef

Donmall, B. G. (Ed.). (1985). Language awareness (NCLE papers and reports, Vol. 6). London:

Centre for Information on Language Teaching and Research. 
Donmall-Hicks, B. G. (1997). The history of language awareness in the United Kingdom. In L. van Lier \& D. Corson (Eds.), Encyclopedia of language and language education: Knowledge about language (Vol. 6, pp. 21-30). Boston: Kluwer.

CrossRef

Dörnyei, Z. (2001). Teaching and researching motivation. Harlow: Longman.

EDiLiC. (2009). Education et Diversité Linguistique et Culturelle. http://www.edilic.org/gb/gb_index. php. Accessed 8 July 2015.

European Commission. (2007). Final report: High level group on multilingualism. Luxembourg: European Communities. Retrieved from http://ec.europa.eu/education/policies/lang/doc/multireport en.pdf.

Fairclough, N. (Ed.). (1992). Critical language awareness (Real language series). London: Longman.

Fehling, S. (2008). Language awareness und bilingualer. Unterricht Eine komparative Studie (2nd ed.). Frankfurt am Main: Peter Lang.

Finkbeiner, C. (2015). Responding to cultural and linguistics diversity through the TRANSABCs project: Reports and results. In C. Finkbeiner \& A. M. Lazar (Eds.), Getting to know ourselves and others through the ABC's. A journey toward intercultural understanding (pp. 11-46). Charlotte: Information Age Publishing.

Finkbeiner, C. \& Fehling, S. (2006). Investigating the role of awareness and multiple perspectives in intercultural education. In P. R. Schmidt \& C. Finkbeiner (Eds.), The ABC's of Cultural Understanding and Communication: National and International Adaptations (pp. 93-110). Greenwich: Information Age Publishing.

Goethals, M. (1993). Language awareness in Belgium: More of an implicit fact than a clear curriculum item. Language Awareness, 2(1), 15-24. doi:10.1080/09658416.1993.9959815. CrossRef

Gordon, R. G. (2005). Ethnologue: Languages of the world (15th ed.). Dallas: SIL International. 
Guardiano, C., Favilla, M. E., \& Calaresu, E. (2007). Stereotypes about English as the language of science. In A. Carli \& U. Ammon (Eds.), Linguistic inequality in scientific communication today (AILA review, Vol. 20, pp. 53-71). Amsterdam/Philadelphia: John Benjamins.

Hamel, R. E. (2007). The dominance of English in the international scientific periodical literature and the future of language use in science. In A. Carli \& U. Ammon (Eds.), Linguistic inequality in scientific communication today (AILA review, Vol. 20, pp. 53-71). Amsterdam/Philadelphia: John Benjamins.

Hawkins, E. (1987a). Awareness of language: An introduction (Rev. Ed.). Cambridge: Cambridge University Press.

Hawkins, E. (1987b). Modern languages in the curriculum (Rev. Ed.). Cambridge: Cambridge University Press.

Helot, C., \& Young, A. (2002). Bilingualism and language education in French primary schools: Why and how should migrant languages be valued? Language Awareness, 5(2), 96-112.

James, C. (1996). Cross-linguistic approaches to language awareness. Language Awareness, 5(3-4), 138-148 (special issue).

CrossRef

James, C., \& Garrett, P. (1991). The scope of language awareness. In C. James \& P. Garrett (Eds.), Language awareness in the classroom (Applied linguistics and language study, pp. 3-20). London: Longman.

Krumm, H.-J. (2001). Kinder und ihre Sprachen - lebendige Mehrsprachigkeit. Wien: Eviva.

Language Awareness. (1992). Language awareness: Wat is dat? Language Awareness, 1(1), 1-3. doi:10.1080/09658416.1992.9959798.

CrossRef

Lasagabaster, D., \& Huguet, A. (Eds.). (2007). Multilingualism in European bilingual contexts:

Language use and attitudes (Multilingual matters, Vol. 135). Clevedon/Buffalo: Multilingual Matters. 
Martin, B. (2012). Coloured language: Identity perception of children in bilingual programmes. Language Awareness, 21(1-2), 33-56. doi:10.1080/09658416.2011.639888.

CrossRef

Palfreyman, D. (Ed.). (2007). Editorial online media: New dimensions for language awareness . Language Awareness (special issue), 16(1), 1-6.

Perregaux, C. (2005). L'éveil aux langues, une vraie histoire européenne ...pour s'ouvrir sur le monde. In Schweizerische Konferenz der kantonalen Erziehungsdirektoren (EDK) \& Conférence suisse des directeurs cantonaux de l'instruction publique (Eds.), Lernen durch die Sprachenvielfalt:

Schlussbericht zum Projekt JALING Suisse. Apprendre par et pour la diversité linguistique Rapport final sur le projet JALING Suisse (pp. 15-25). Biel: Ediprim AG.

Pliska, E. (2015). Einstellungen zu Muttersprachen und Fremdsprachen. Eine empirische Studie mit Schülerinnen und Schülern in Bosnien-Herzegowina (Language culture literacy). Frankfurt am Main: Peter Lang.

Riemersma, A. (2011). Introduction. In Mercator European Research Centre on Multilingualism and Language Learning (Ed.), Trilingual Primary Education in Europe. Some developments with regard to the provisions of trilingual primary education in minority language communities of the European Union (pp. 7-11). Leeuwarden/Ljouwert: Fryske Akademy.

Schluer, J. (2014). Writing for publication in linguistics: Exploring niches of multilingual publishing among German linguists. Journal of English for Academic Purposes, 16, 1-13.

doi:10.1016/j.jeap.2014.06.001.

CrossRef

Schmidt, P. R., \& Finkbeiner, C. (Eds.). (2006). The ABC's of cultural understanding and communication: National and international adaptations. Greenwich: Information Age Publishing.

Schweizerische Konferenz der kantonalen Erziehungsdirektoren (EDK), \& Conférence suisse des directeurs cantonaux de l'instruction publique (Eds.). (2005). Lernen durch die Sprachenvielfalt: Schlussbericht zum Projekt JALING Suisse. Apprendre par et pour la diversité linguistique Rapport final sur le projet JALING Suisse. Biel: Ediprim AG. 
van Parijs, P. (2007). Tackling the Anglophone's free ride: Fair linguistic cooperation with a global lingua franca. In A. Carli \& U. Ammon (Eds.), Linguistic inequality in scientific communication today (AILA review, Vol. 20, pp. 72-86). Amsterdam/Philadelphia: John Benjamins.

\section{Footnotes}

1

$\mathrm{KAL}$ is sometimes used as a synonym for language awareness.

2

This perspective has come to be called critical language awareness.

$\underline{3}$

These domains are still referred to today. See, for example, Fehling ( 2008).

$\underline{4}$

The ability to talk about one's knowledge about language (e.g., pronunciation, grammar, lexicon, discourse) is referred to as metalinguistic awareness.

$\underline{5}$

The difference between a language and a dialect is often difficult to define. 